\title{
Five glassy-haired Hyaloscyphaceae
}

\author{
SEPPO HUHTINEN
}

\begin{abstract}
HUHTINEN, S. 1988: Five glassy-haired Hyaloscyphaceae. - Karstenia 27: 8-14.
Five rare species of glassy-haired Hyaloscyphaceae are treated and illustrated, three of them from their type specimens. Unguiculella xylemicola Bøhler is shown to be a synonym of Hyalopeziza pani (Vel.) L. Holm \& K. Holm and this species is transferred to the genus Urceolella Boud. on the basis of the chemical characters of the hairs. The type of Urceolella curvipila (Karst.) Raschle is shown to have multiseptate hairs. This feature is coupled with $\mathrm{KOH}$-instability of the solidifying substance. A parallel case is seen in the type of $U$. appressipila Graddon and it is suggested that hair septation should be accepted in Urceolella. A recent collection of Unguicularia raripila Höhnel, which was formerly known only from the type collection, is treated and a new combination is proposed, Hyalopeziza raripila (Höhnel) Huhtinen, n. comb. The material studied offers further proof that solid vs. luminal hairs is not a valid generic character in the glassy-haired Hyaloscyphaceae.
\end{abstract}

Seppo Huhtinen, Department of Biology, University of Turku, SF-20500 Turku, Finland

Recently, when presenting three new species of the glassy-haired Hyaloscyphaceae, I adopted the chemical approach outlined by Korf \& Kohn (1980). The present paper is a continuation of those studies (cf. Huhtinen 1987a, 1987b, 1987c) and the same classification strategy is followed. The methods are those described earlier (Huhtinen 1987a).

Two of the species treated below show that full reliance cannot be placed on solid vs. luminal hairs even at the species level. As hairs seem to be important generic characters in so many cases, we have to decide whether to stress hair shape and septation or hair chemistry in the glassy-haired Hyaloscyphaceae. The use of hair chemistry at the generic level results in larger genera than those resulting from traditional taxonomic characters. Within the genera characterized by uniformity in the hair chemistry, we can distinguish subgenera using the traditional characters such as hair shape or curvature. At present we do not even know whether all glassy-haired taxa should be separated at the generic level from the rest of the Hyaloscyphaceae and there is little hope of finding a wholly natural grouping. A more natural classification is commonly achieved by using more characters to reduce subjectivity, but in the present group of fungi the use of morphology and histochemistry at the same level inevitably results in conflict.
In view of our present limited knowledge, we should select a classification strategy combining the minimum of nomenclatural burden with relatively natural genera. To my mind, this can be achieved with the classification of the glassy-haired genera proposed by Korf and Kohn (1980). The chemical characters on which it is based, however, are not used in the generic delimitation of the rest of the Hyaloscyphaceae. Whether this can be considered to prevent the use of histochemistry depends on whether we accept a glassy-haired line of development along with a parallel line characterized by thin-walled hairs. It may be noted that the conventional classification of glassy-haired taxa is actually based on this assumption.

Urceolella pani (Vel.) Huhtinen, comb.nov.

$$
\text { -Figs. 1-3 }
$$

Hyaloscypha pani Vel., Monogr. Discom. Bohemiae 1: 285 , 1934. Holotype: [Czechoslovakia], Bohemia, Jevany, on dead leaves of Lycopodium clavatum, 10.X.1925 Velenovský, PRM 149707 (not studied). — Hyalopeziza pani (Vel.) L. Holm \& K. Holm, Karstenia 21: 62. 1981.

Unguiculella xylemicola Bøhler, Norw. J. Bot. 21: 95. 1974. Holotype: [Norway], Akershus, Bærum, Isidalen, on vascular bundles of dead petioles of Dryopteris filix-mas, 

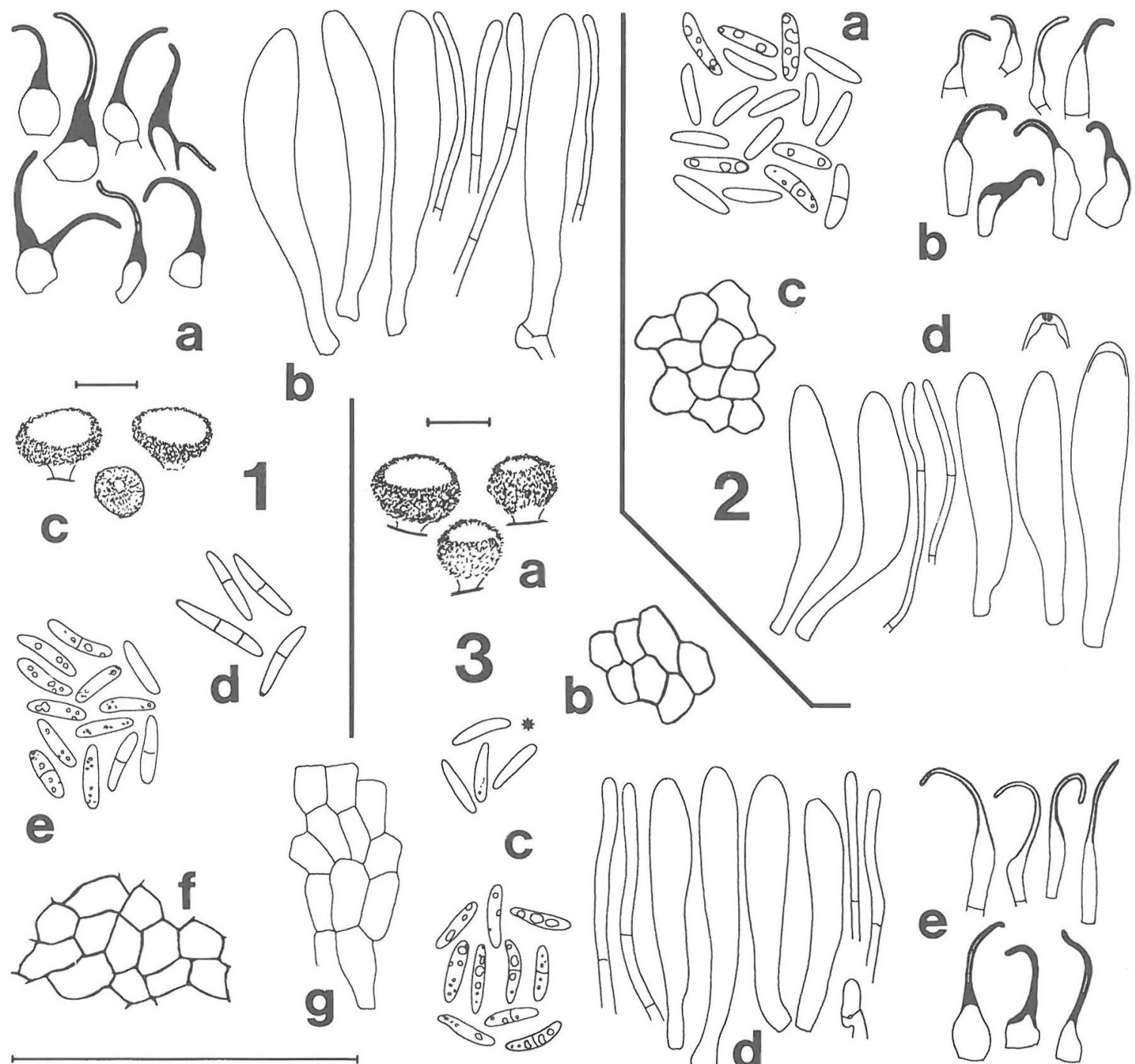

Figs. 1-3. Urceolella pani. - 1: Paratype of Unguiculella xylemicola, Bøhler 176/69. a) hairs, b) asci and paraphyses, c) dried apothecia, d) free conidia characterizing the mounts, e) spores, f) outermost excipulum, g) inner excipulum. -2 : Holotype of $U$. xylemicola. a) spores in Melzer's reagent, b) hairs in Melzer's reagent, c) outermost excipulum, d) asci and paraphyses in Melzer's reagent. - 3: Hyalopeziza pani, Holm \& Holm 2239c. a) dried apothecia, b) outermost excipulum, c) spores, marked in Melzer's reagent, d) asci and paraphyses, e) hairs. - Scale $50 \mu \mathrm{m}$, for apothecia $100 \mu \mathrm{m}$, all in cotton blue unless otherwise stated.

12.IX.1969 Bøhler 226/69, O (studied). - Hyalopeziza xylemicola (Bøhler) Schneller, Mykol. Helvetica 2: 84. 1986.

Apothecia gregarious to solitary, first globosecupulate, later cupulate, shortly stipitate to substipitate, up to $150 \mu \mathrm{m}$ in diam when dried, pure white to yellowish white when dried, hairs white and covering the receptacle except for the stipe.
Ectal excipulum of two layers, the outermost thin, formed of textura angularis, cells $6-11 \times 4-8 \mu \mathrm{m}$, inner layers of textura prismatica, cells $8-10 \times$ 4-6 $\mu \mathrm{m}$; walls hyaline to, more rarely, faintly brown, membranaceous to $0.5-0.8 \mu \mathrm{m}$ thick, I-, often unstained but in places staining clearly in cotton blue and ammoniacal Congo red, the staining reaction due to some extraneous substance. 
Hairs up to $25 \mu \mathrm{m}$ long, hyaline, smooth, aseptate, bases narrow, 2-3 $\mu \mathrm{m}$ broad, or clearly widened and up to $6 \mu \mathrm{m}$ broad, hairs apically always narrow, cylindrical to slightly tapering, $0.6-1.0 \mu \mathrm{m}$ broad, curved, solid to luminal; hair walls apically thickened and refractive, thin at the base, rarely thin throughout, with a dual structure, wall proper retaining its structure in $10 \% \mathrm{KOH}$, the solidifying substance either dissolved, or losing refractiveness after exposure to $\mathrm{KOH}$, walls I-, not staining in cotton blue or ammoniacal Congo red when intact, but the whole hair staining in Congo red after exposure to $\mathrm{KOH}$; on the flanks the narrow apical parts may arise from relatively unspecialized cells of the ectal excipulum, occasionally two narrow apices arise from the same cell.

Asci cylindrical to clavate, arising from croziers, 33-45 × 5-8 $\mu \mathrm{m}$, eight-spored, pore wall moderately to clearly amyloid without $\mathrm{KOH}$ pretreatment (pani) to amyloid only after $\mathrm{KOH}$ pretreatment (xylemicola). Ascospores ellipsoid to subfusoid, 7-10 x 1.8-2.0 $\mu \mathrm{m}$ aseptate to rarely uniseptate while still in the ascus, more often uniseptate after being discharged, septum I-, with a few prominent guttulae in cotton blue, Congo red and water, but in Melzer's reagent also appearing aguttulate, guttulae not staining in Melzer's reagent or cotton blue. Paraphyses varying from filiform and $1.5 \mu \mathrm{m}$ broad to cylindrical to somewhat clavate, $2.0-2.5 \mu \mathrm{m}$ broad, devoid of pigments, not exceeding the asci, terminal cells 13$25 \mu \mathrm{m}$ long.

Material studied: Norway. Akershus (see the type of Unguiculella xylemicola); same site and ecology, 25.VIII.1969 Bøhler 176/69 (O, paratype). - Sweden. Uppland: Åland, Rövarkulan, on dead Lycopodium clavatum L., 19.IX.1980 Holm \& Holm 2239c (UPS, TUR); Dalby, Hammarskog, on dead Lycopodium complanatum L. (= Diphasiastrum complanatum (L.) J. Holub), 16.XI.1980 Holm \& Holm 2272d (UPS, amongst Hamatocanthoscypha laricionis (Vel.) SvrCek).

The material of Hyalopeziza pani (Vel.) L. Holm $\& \mathrm{~K}$. Holm and Unguiculella xylemicola Bøhler studied by me showed marked uniformity. Apart from the substrate, the only differences are seen in spore shape and in normal versus concealed amyloid reaction of the asci. Considerable overlapping exists in spore size and shape, but the spores of $H$. pani are more frequently subfusoid and slightly narrower than the ellipsoid and broader spores of $U$. xylemicola. Recognition at infraspecific level should not be considered until additional material from a wider selection of the possible substrates is obtained. It is unclear to me in which way we should weigh the amyloid reaction of asci that becomes visible only after $\mathrm{KOH}$ pretreatment.
I have also seen the type of Hyaloscypha pani Vel. (in PRM), which is a very scanty collection and was thus not studied, but a slide from the type collection was studied by Holm and Holm (1981) when they made the new combination Hyalopeziza pani. Furthermore, their material is a very close match to Velevovsky's (1934) original diagnosis and the risk of taxonomic confusion is small.

The new combination with Urceolella Boud. follows the generic delimitations outlined by Korf and Kohn (1980). As shown earlier (Huhtinen 1987a), the chemical characters of the hairs are those of an Urceolella. The chemical characters of the excipulum are more heterogenous and the amount of extraneous, cyanophilous substance is smaller than in many other species of Urceolella Recently, Schneller (1986) proposed a combination with Hyalopeziza Fuckel; he had presumably not observed that apically luminal and solid hairs are equally common. Bøhler (1974) also failed to see the lumen when describing Unguiculella xylemicola.

Although Urceolella pani has an outermost layer of textura angularis, it is not to be considered an alien element in the genus. A major part of the excipulum is composed of textura prismatica and the angular cells at the surface often serve as hair bases.

\section{Urceolella appressipila Graddon -Fig. 4}

Urceolella appressipila Graddon, Trans. Br. mycol. Soc. 87: 333. 1986. Isotype: [Great Britain], Herefordshire, Kerne Bridge, in woodland litter (on leaf remnants), III.1985 Graddon 4228, TUR (studied).

Apothecia scattered, cupulate, shortly to prominently stipitate, up to $200 \mu \mathrm{m}$ in diam when dried, flanks slightly brownish when dried but the colour hidden by a dense cover of appressed, snow-white hairs; stipe stout, naked, up to $120 \mu \mathrm{m}$ long, basally brownish.

Ectal excipulum of large-celled textura prismatica, cells $12-16 \times 4-10 \mu \mathrm{m}$, becoming narrower in the inner layers; walls hyaline to slightly brown at stipe base, thin, ca. $0.2-0.3 \mu \mathrm{m}$ thick, I-, staining clearly in cotton blue and Congo red.

Hairs up to $130 \mu \mathrm{m}$ long, $2.5-3.5 \mu \mathrm{m}$ broad, cylindrical, hyaline, blunt, smooth, flexuose, luminal, aseptate to multiseptate, not exuding any resinous matter; walls thickened, refractive, with a dual structure, wall proper enclosing a layer of solidifying substance, I-, not staining in cotton blue or Congo red, the solidifying substance abruptly swelling in $7 \% \mathrm{KOH}$, after which the shape of the hairs is lost, wall proper and plasma congophilous after repeated staining with ammoniacal Congo red, solidifying substance disappearing. 

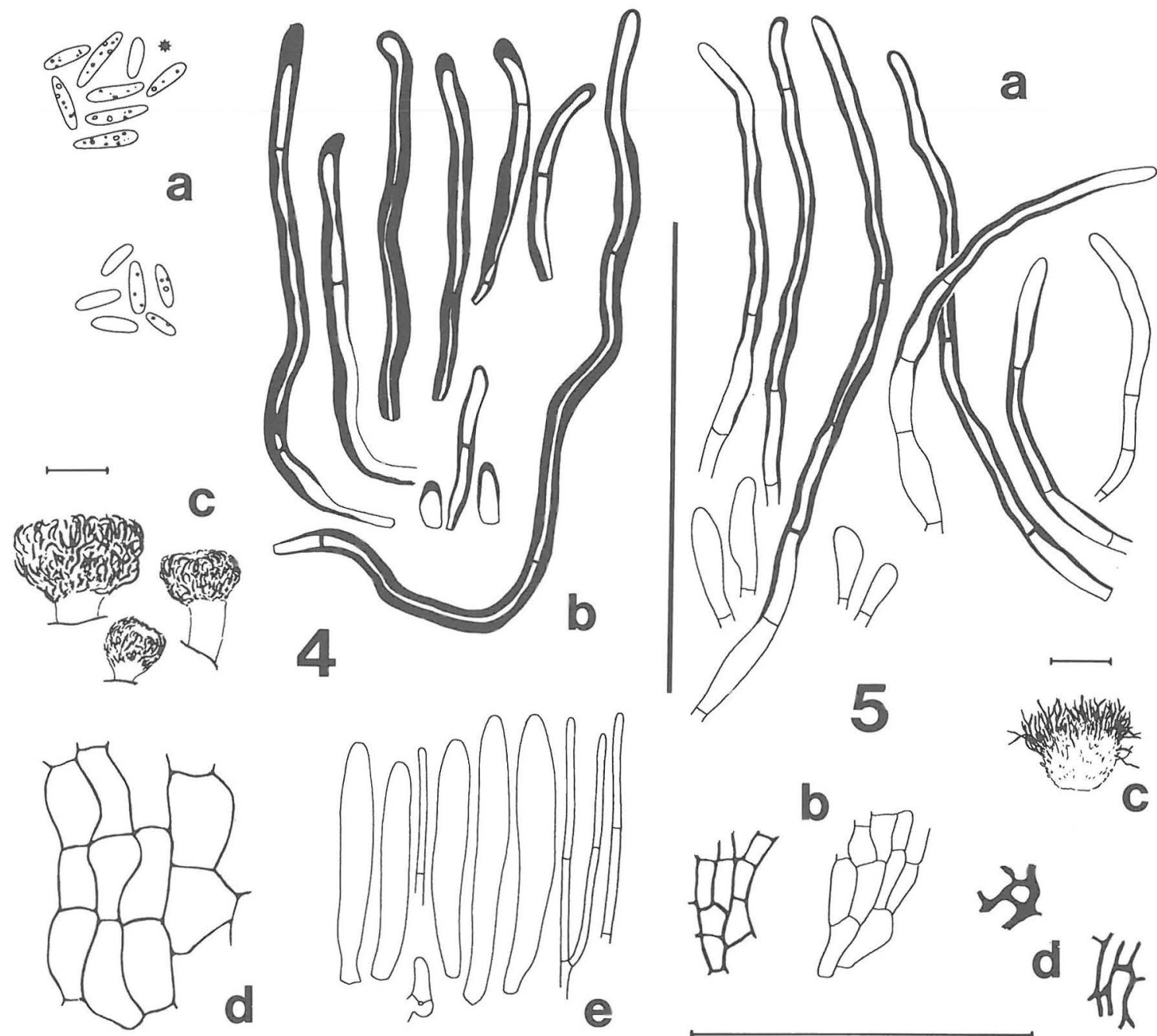

Figs. 4-5. Septate-haired species of Urceolella. - 4: Isotype of Urceolella appressipila. a) spores, marked in Melzer's reagent, b) hairs, c) dried apothecia, d) ectal excipulum, e) asci and paraphyses. - 5: Holotype of Urceolella curvipila. a) hairs and marginal cells, b) ectal excipulum, c) dried apothecium, d) fragments showing maximal wall thickness of excipulum at base (upper) and on flanks (lower). - Scale $50 \mu \mathrm{m}$, for apothecium $100 \mu \mathrm{m}$, all in cotton blue unless otherwise stated.

Asci cylindrical, arising from croziers, $30-42 \times$ 3.5-6.0 $\mu \mathrm{m}$, eight-spored, pore wall clearly amyloid without $\mathrm{KOH}$ pretreatment, apex conical, slightly thickened. Ascospores ellipsoid to subfusoid, 6-10 x 2.0-2.5 $\mu \mathrm{m}$, aseptate, minutely and indistinctly guttulate in cotton blue, more clearly guttulate in Melzer's reagent. Paraphyses filiform, $1.5-1.8 \mu \mathrm{m}$ broad, not exceeding the asci, terminal cells $15-20 \mu \mathrm{m}$ long.

The cylindrical-flexuose, blunt hairs of Graddon's new species are in general identical with those char- acterizing the genus Urceolella, as outlined by, e.g., Raschle (1977). They cast new light on the genus, however, in being typically septate. The hair chemistry, showing $\mathrm{KOH}$-unstable and non-stainable wall material, also strengthens the view that septate hairs should be accepted in Urceolella. This was tentatively suggested in connection with the description of $U$. conspicua Huhtinen, and $U$. curvipila (Karst.) Raschle, treated below, brings the number of species with septate hairs in the genus up to three (cf. Huhti- 
nen 1987a). Correspondingly, the genus Hyalopeziza contains species with typically aseptate hairs, namely $H$. trichodea (Phill. \& Plowr.) Raitv. and $H$. niveocincta (Graddon) Raschle. These two were accepted in the genus on the basis of their hair chemistry. Recently two further species were included by me (Huhtinen 1987a).

It now seems that the presence vs. absence of septa is not an absolutely reliable character for separating these two genera, but is subject to variation. In Urceolella appressipila aseptate hairs form a small minority, whereas in $U$. curvipila they are hardly seen at all. For a perfect continuum we still require a species in which septate hairs are rare.

\section{Urceolella curvipila (Karst.) Raschle}

Helotium carestianum (Rabenh.) Karst. ssp. curvipilum Karst., Bidr. Kännedom Finl. Nat. Folk 19: 162. 1871. Holotype: [Finland], Etelä-Häme, Tammela, Mustiala, Haarankorpi, on Carex vesicaria L. arising from a sclerotium, 16.IX.1869 Karsten, $\mathrm{H}$ (studied).

The holotype has been studied and treated twice, first by Dennis (1950) and then by Raschle (1977). It is very scanty and I managed to find only two juvenile, loose apothecia in the envelope. Like U. appressipila, this is a critical species for the delimitation of Urceolella. The hairs are always multiseptate; this feature was not noted by Raschle and was omitted from the illustration by Dennis (though mentioned in the text). The hairs lose their refractiveness and partly also their structure upon exposure to $7 \% \mathrm{KOH}$. In addition, the refractive parts of the hairs are impermeable to Congo red. The negative reaction in Melzer's reported by Raschle (1977) and the strong staining of the excipulum in cotton blue also agree with the histochemical delimitation of Urceolella.

The asci of $U$. curvipila arise from croziers. The ectal excipulum is fairly thick-walled in the outermost layer, the cell walls measuring $0.4-0.8 \mu \mathrm{m}$. The inner layers of the excipulum are thin-walled. At the base the structure becomes textura angularis with clearly gelatinized walls. The dried apothecia are very light yellowish on the flanks, the overall colour being modified by the white hairs.

Raschle (1977) stressed the difference in the iodine reaction of the asci between the present species and Urceolella seminis (Cooke \& Phill.) Dennis. The descriptions and the ecology are, however, so alike that conspecificity is very probable and should be verified on another set from Libert's exsiccatum than the possibly $\mathrm{KOH}$-treated specimen in Kew.

$\begin{aligned} & \text { Hyalopeziza raripila (Höhnel) } \\ & \text { comb.nov. }\end{aligned}$
$\begin{aligned} & \text { Huhtinen, } \\ & \text {-Fig. } 6\end{aligned}$

Unguicularia raripila Höhnel, Sitz.ber. Keiserl. Akad. Wissensch. Wien, Abt. 1, 126: 329. 1917. Type: [Austria], Niederösterreich, Pfarrgarten am Sonntagsberg, V.1916, Strasser, FH (not studied).

Apothecia gregarious, cupulate with a somewhat narrowed base, later appearing sessile, up to $200 \mu \mathrm{m}$ in diam when fresh and up to $150 \mu \mathrm{m}$ when dried, yellowish to brownish when dried, hairs white but not greatly changing the overall colouring of the apothecia.

Ectal excipulum of textura angularis, cells 6$10(-15) \times 4-8(-10) \mu \mathrm{m}$, at the margin more prismatic, 5-6 x 4-5 $\mu \mathrm{m}$; walls hyaline, occasionally faintly brown at the base, colour located in the wall, walls slightly thickened (ca. $0.5 \mu \mathrm{m}$ ), refractive, Ieven after $\mathrm{KOH}$ pretreatment, in the outer excipulum not staining in cotton blue, the inner excipulum with extraneous, cyanophilous substance.

Hairs up to $35 \mu \mathrm{m}$ long, 3-5 $\mu \mathrm{m}$ broad at the base, aseptate, tapering to a 1-2 $\mu \mathrm{m}$ broad apex, luminal to solid, not exuding any resinous matter; hair walls hyaline, smooth when fresh in water, glassy, I- even after $\mathrm{KOH}$ pretreatment, not staining in cotton blue or ammoniacal Congo red, unchanged in $40 \% \mathrm{KOH}$.

Asci cylindrical-clavate, arising from croziers, 40 $55(-65) \times 6-8 \mu \mathrm{m}$, eight-spored, pore wall I-, clearly amyloid after $\mathrm{KOH}$ pretreatment. Ascospores ellipsoid, straight to slightly curved, 8-12 x 2-3 $\mu \mathrm{m}$, aseptate, prominently guttulate. Paraphyses cylindrical, 1.5-2.0 $\mu \mathrm{m}$ broad, not exceeding the asci, terminal cells $15-25 \mu \mathrm{m}$ long.

Material studied: Finland. Varsinais-Suomi: Turku, Ruissalo, Botanical Garden, on old herbaceous stems, 5.VII.1985 Huhtinen $85 / 13$ (TUR).

To my knowledge this is the second reported collection of this rare species. The type was studied by Raschle (1977) and the present material matches his description well. Hyalopeziza arctica Raitv. seems to be very closely related to $H$. raripila, as judged from the short description by Raitviir (1985).

As already pointed out, many species that have been reported to bear solid hairs, actually have luminal hairs as a typical character. In the present species the lumen is seen in cotton blue mounts at $\times 1500$ magnification. There are also numerous hairs in which the lumen is either lacking or totally obscured by the walls; this variation is seen in each apothecium.

The hairs show the typical features of the genus Hyalopeziza. The solidifying material remains intact in $40 \% \mathrm{KOH}$. Repeated heating in ammoniacal Con- 

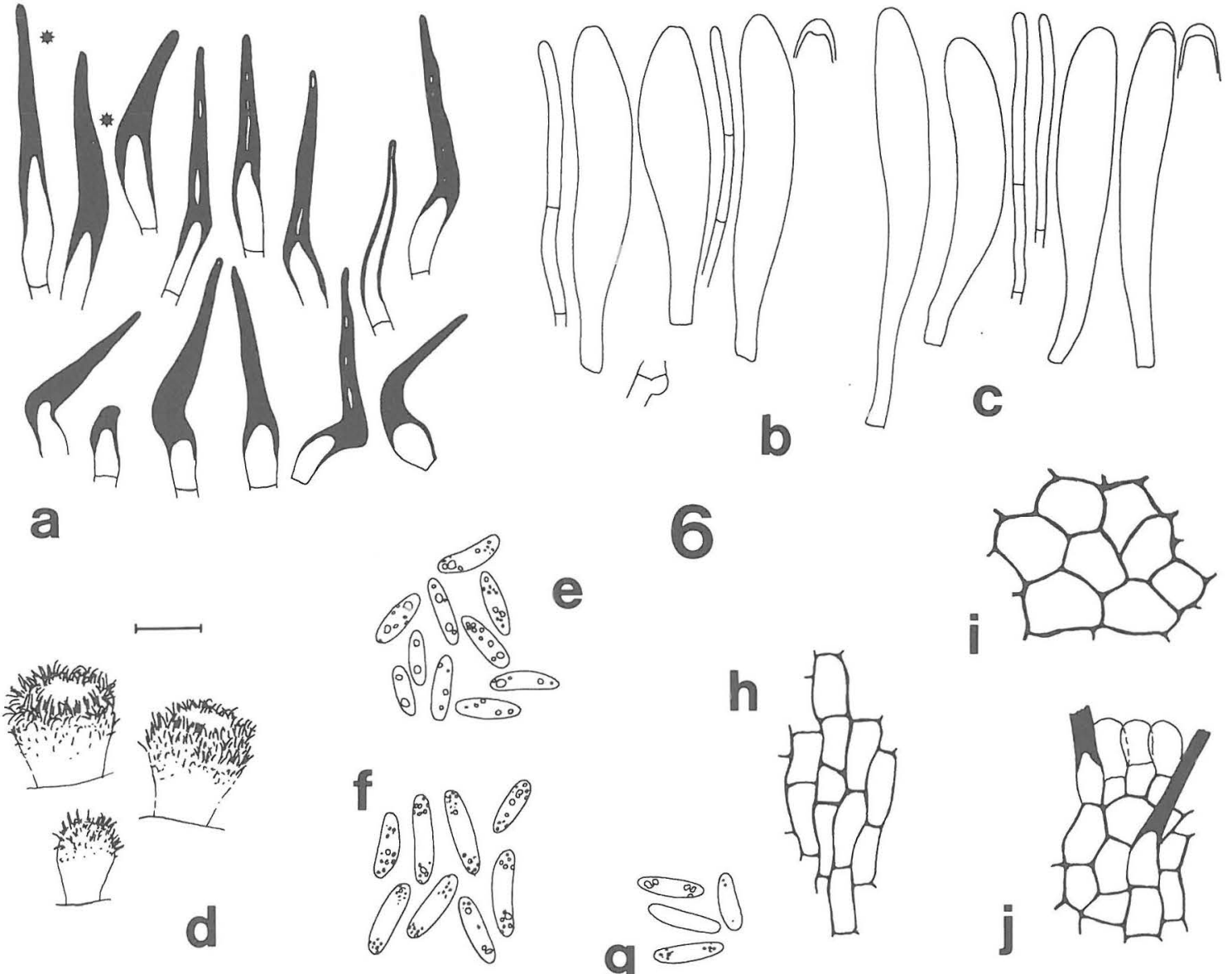
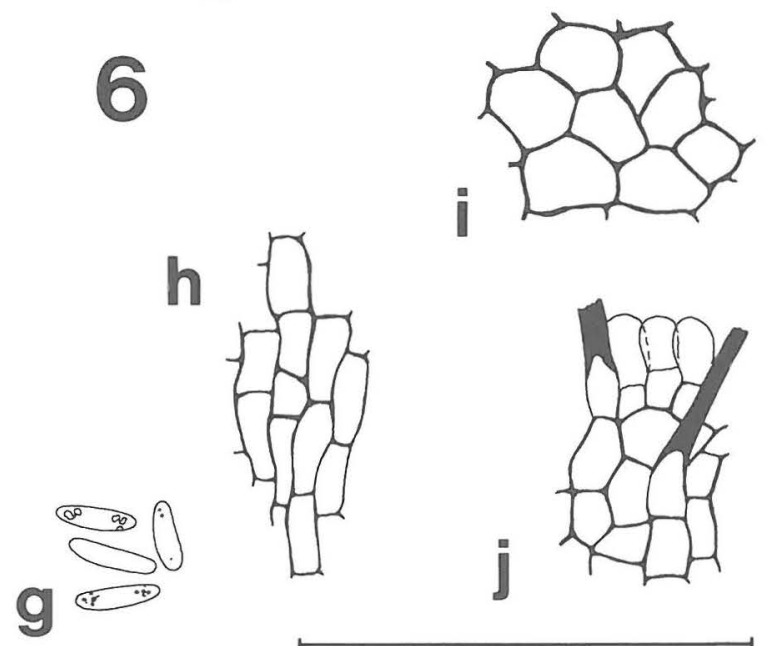

Fig. 6. Hyalopeziza raripila, Huhtinen 85/13. a) hairs, marked fresh in water, b) asci and paraphyses, fresh in water, c) asci and paraphyses from dried material, in cotton blue, d) fresh apothecia, e) spores in cotton blue, f) spores, fresh in water, g) spores in Melzer's reagent, h) inner excipulum in Melzer's reagent, i) outermost excipulum in Congo red, j) detail from margin, in Melzer's reagent. - Scale $50 \mu \mathrm{m}$, for apothecia $100 \mu \mathrm{m}$.

go red result in seemingly totally red-coloured hairs, but the stain is absorbed by the plasma, while the wall (or most of it) remains hyaline. The excipular structure is slightly different from that typical of the Hyaloscyphaceae and textura prismatica is seen only close to the margin and in the inner layers of the excipulum.

Acknowledgements. Dr. W.D. Graddon is thanked for kindly sending an isotype and some other collections to the Herbarium of the University of Turku. This study was supported financially by the Academy of Finland.

\section{References}

Bøhler, H.C. 1974: Taxonomical studies on some Norwegian Helotiales (Ascomycetes) on fern remains. - Norw. J. Bot. 21: 79-100.

Dennis, R.W.G. 1950: A revision of the British Helotiaceae in the Herbarium of the Royal Botanic Gardens, Kew, with notes on related European species. - Mycol. Pap. 62: 1-216.

Holm, L. \& Holm, K. 1981: Ascomycetes on Nordic Lycopods. - Karstenia 21: 57-72.

Huhtinen, S. 1987a: Three new species, and the histochemical delimitation of genera in the glassy-haired Hyaloscyphaceae. - Mycotaxon 29: 267-283. 
- 1987b: Taxonomic studies in the genera Protounguicularia, Arachnopeziza and Dematioscypha. - Mycotaxon 30: 928.

- 1987c: The genus Protounguicularia in Europe. - Beitr. Kenntnis Pilze Mitteleuropas 3: 457-464.

Korf, R.P. \& Kohn, L. 1980: Revisionary studies in the Hyaloscypheae 1. On genera with "glassy" hairs. - Mycotaxon 10: 503-512.

Raitviir, A. 1985: Four new species of the Hyaloscyphaceae. - Fol. Crypt. Estonica 23: 5-7.

Raschle, P. 1977: Taxonomische Untersuchungen an Ascomyceten aus der Familie der Hyaloscyphaceae Nannfeldt. - Sydowia 29: 170-236.

Schneller, J.J. 1986: Hyalopeziza xylemicola (Bøhler) Schneller comb. nov., ein Ascomycet (Helotiales) auf Farnresten, neu für Mitteleuropa. - Mycol. Helvetica 2: 83-86.

Velenovský, J. 1934: Monographia Discomycetum Bohemiae. - 436 pp., 31 tables. Pragae.

Accepted for publication on 24 April 1987 